\title{
MOTIVASI BELAJAR DAN TINGKAT BELAJAR MANDIRI DALAM KAITANNYA DENGAN PRESTASI BELAJAR MAHASISWA
}

\author{
Budiman Tampubolon \\ Fakultas Keguruan dan Ilmu Pendidikan, Universitas Tanjungpura, Pontianak, Indonesia \\ Email: budiman.tampu@gmail.com
}

\begin{abstract}
Abstrak. Tujuan penelitian ini adalah untuk mengetahui motivasi dan keterampilan belajar mandiri mahasiswa Program Studi Pendidikan Geografi Fakultas Keguruan dan Ilmu Pendidikan Universitas Tanjungpura Pontianak. Metode yang digunakan dalam penelitian ini adalah metode deskriptif dengan pendekatan kuantitatif. Sampel penelitian adalah mahasiswa program studi geografi semester dua dan empat yang memiliki IPK $\leq 3,00$. Teknik pengumpulan data menggunakan angket dan wawancara dengan alat pengumpulan data lembar angket dan pedoman wawancara. Hasil penelitian mahasiswa semester II berdasarkan perhitungan diperoleh R_ (y.x_1 x_2) sebesar 0,216. Setelah dilakukan pengujian signifikansi koefisien korelasi berganda dengan uji $\mathrm{F}$ diperoleh harga Fh sebesar 0,493. Jika dibandingkan dengan harga Ftabel dengan $\mathrm{dk}$ pembilang $=\mathrm{k}=2$ dan $\mathrm{dk}$ penyebut $=13$ dengan tingkat kesalahan 5\% maka nilai Ftabel adalah 3,80. Ternyata harga Fhitung lebih kecil dari Ftabel $(0,493<3,80)$, sehingga Ha ditolak dan Ho diterima. Kesimpulannya adalah tidak ada hubungan yang positif antara motivasi belajar dan kemandirian belajar dengan prestasi belajar siswa. Hasil penelitian mahasiswa semester IV berdasarkan perhitungan diperoleh $\mathrm{R}_{-}$(y.x_1 $\mathrm{X} \_2$ ) sebesar 4,709. Setelah dilakukan pengujian signifikansi koefisien korelasi berganda dengan uji $\mathrm{F}$ diperoleh harga Fh sebesar 10,479. Jika dibandingkan dengan harga Ftabel dengan dk pembilang $=2$ dan dk penyebut $=20$ dengan taraf kesalahan 5\% maka didapatkan harga Ftabel = 3,49 Ternyata harga Fhitung lebih besar dari Ftabel (10,479> 3.49) maka Ha diterima dan Ho ditolak. Kesimpulannya adalah ada hubungan positif antara motivasi belajar dan kemandirian belajar secara bersama-sama dengan prestasi belajar mahasiswa semester IV.
\end{abstract}

Kata Kunci: Motivasi Belajar, Kemandirian Belajar, Prestasi

\section{Pendahuluan}

Belajar adalah suatu proses atau usaha yang menjadi dasar atau fundamental dalam pendidikan setiap individu. Dengan adanya belajar setiap individu mengallami berbagai perubahan baik dalam tingkah laku, pengetahuan, pola pikir, keterampilan dan hal-hal lainnya yang berkaitan dengan kehidupannya.

Pengertian belajar menurut menurut Gagne dan Briggs (dalam M. Djauhar Siddiq, dkk. 2008; 1.4) bahwa " belajar adalah suatu proses di mana suatu organisma berubah perilakunya sebagai akibat pengalaman". Winataputra $\mathrm{dkk}$,

1997, 2.3 mendefinisikan belajar adalah" suatu proses di mana suatu organisma berubah perilakunya sebagai akibat pengalaman". Winkel (1996:53) mengatakan bahwa "belajar adalah suatu aktivitas mental/psikis yang berlangsung dalam interaksi aktif dengan lingkungannya, yang menghasilkan perubahan-perubahan, pengetahuan, pemahaman, keterampilan dan nilai sikap, serta perubahan itu bersifat secara relatif konstan dan tetap". Sedangkan yang dimaksud motivasi belajar adalah keinginan yang mengaktifkan, menggerakkan, menyalurkan dan mengarahkan sikap dan perilaku individu untuk belajar.

Tentunya akan ada perbedaan yang jelas di dalam setiap individu sebelum dan sesudah dia belajar mengenai suatu hal. Belajar dapar berasal dari pengalaman, bacaan/pengetahuan, pengamatan, akrivitas, fisik dan yang lainnya. Untuk membentuk individu dengan karakter dan pengetahuan yang baik maka diperlukan proses pembelajaran yang baik dan mengarah kepada halhal yang positif.

Secara umum, belajar adalah suatu proses atau usaha yantg dilakukan oleh setiap individu 
untuk mendapatkan suatu perubahan di dalam kehidupannya baik tingkah laku, pengetahuan, sikap, keterampilan, pola atau daya pikir, nilai kehidupan, dan berbagai kemampuan lainnya yang diperlukan didalam kehidupan. Belajar sudah seharusnya mengarah kepada hal-hal yang positif dan bersifat membangun. Setiap individu dapat belajar dari lingkungan sekitarnya seperti di sekolah, di kampus, lingkungan pergaulan/masyarakat, laboratorium, museum dan yang lainnya.

Belajar mandiri merupakan salah satu kemampuan yang harus dimiliki oleh mahasiswa. Definisi belajar mandiri bukan berarti belajar sendiri, yaitu hanya memegang setumpuk buku yang coba dibaca semua dan diselesaikan sendiri. Kata kunci dari belajar mandiri adalah "inisiatif sendiri". Belajar mandiri berarti belahar secara berinisiatif, dengan ataupun tanpa bantuan orang lain di dalam belajar.

Saat sekarang ini sumber pengetahuan sudah sangat beragam seperti dari buku, jurnal, internet, makalah, bertanya kepada orang lain atau dosen, juga termasuk hasil melakukan eksperimen dan berpartisipasi pada seminar. Dengan inisiatif sendiri pelajar dan mahasiswa dapat menggunakan semua sumber pengetahuan untuk membangun pengetahuan baik dalam dunia pendidikan formal maupun karena tujuan pribadi. Belajar mandiri dalam institusi formal selalu melibatkan institusi, guru/dosen, dan unit-unit pendukung lainnya.

Sebagai mahasiswa yang mandiri tidak harus mengetahui semua hal, juga tidak diharapkan menjadi mahasiswa jenius ysng tidk membutuhkan bantuan orang lain. Salah satu prinsip belajar mandiri adalah mahasiswa mampu mengetahui kapan mahasiswa membutuhkan bantuan atau dukungan pihak lain, termasuk mengetahui kapan perlu bertemu dengan teman mahasiswa, kelompok belajar. Bantuan/dukungan dapat berupa kegiatan kegiatan saling memotivasi untuk belajar, memotivasi, diri untuk giat belajar. Bantuan/dukungan dapat juga berarti buku literature pendukung, kasus dari koran, perpustakaan, dan hal lain yang tidak berhubungan dengan orang. Belajar mandiri memberikan kesempatan kepada mahasiswa untuk menentukan tujuan belajar, merencanakan proses belajar, menggunakan sumber-sumber belajar yang dipilih, membuat keputusan-keputusan akademis, dan melakukan kegiatan-kegiatan untuk mencapai tujuan belajar.

Program Studi Pendidikan geografi, tujuan dan berbagai bantuan belajar telah ditentukan oleh institusi. Mahasiswa dituntut untuk secara aktif dan mandiri (dengan inisiatif sendiri) menyusun rencana belajar mahasiswa mulai dari mingguan, bulanan, dan semesteran sampai selesai program. Belajar mandiri bukan berarti belajar sendiri. Seringkali orang menyalah artikan belajar mandiri sebagai belajar sendiri. Kesalahan pengertian tersebut terjadi karena pada umumnya mereka yang kuliah di UT cenderung belajar sendiri tanpa tutor atau teman kuliah. Belajar mandiri berarti belajar secara berinisiatif, dengan ataupun tanpa bantuan orang lain, dalam belajar.

Untuk dapat melakukan belajar mandiri diperlukan motivasi belajar. Motivasi belajar adalah dorongan yang timbul dari dalam diri (intrinsik) dan dari luar diri (ekstrinsik) untuk melakukan sesuatu. Motivasi belajar menurut Djamarah (2008, 149), motivasi yang berasal dari dalam diri pribadi seseorang disebut motivasi intrinsik, yaitu motifmotif yang menjadi aktif atau berfungsinya tidak perlu dirangsang dari luar. Hal ini dikarenakan di dalam disi setiap individu sudah ada dorongan untuk melakukan sesuatu. Sedangkan motivasi yang berasal dari luar diri seseorang disebut motivasi ekstrinsik yaitu motif-motif yang aktif dan berfungsi karena adanya perangsang dari luar. Menurut Nasution (1982:77) motivasi memiliki tiga fungsi yaitu:

1. Mendorong manusia untuk berbuat, jadi sebagai penggerak motor yang melepas energi.

2. Menentukan arah perbuatan, yakni kearah tujuan yang hendak dicapai.

3. Menyeleksi perbuatan yang harus dikerjakan yang serasi guna mencapai tujuan, dengan menyisihkan perbuatan-perbuatan yang tidak bermanfaat bagi tujuan tersebut.

Tidak dapat dipungkiri bahwa motivasi belajar mrupakahn salah satu aspek yang berperan signifikan dalam proses tercapainya tujuan pembeklaaran dan motivsi belajar juga akanj mempengaruhi dan dipengaruhi oleh aspek kognitif, afektif dan psikomotor peserta didik

Pengaruh kemajuan teknologi informasi komunikasi terutama penggunaan handphone dikalangan masyarakat mulai anak-anak sampai orang dewasa, khususnya pelajar sampai mahasiswa hampir sebagian besar waktunya digunakan untuk main handphone. Hal ini dimungkinkan banyak pelajar dan mahasiswa yang kurang bahkan tidak membagi waktunya setiap hari untuk belajar mandiri baik di lingkungan sekolah atau kampus tertutama di luar sekolah atau kampus. Dari pengamatan sehari-hari di kampus hampir semua mahasiswa selalu memegang hanpone setiap ada waktu luang 
bahkan sambil berjalan memegang hanpone. Kenyataan ini bisa menimbulkan motivasi belajar semakin menurun yang berpengaruh pada tingkat belajar mandiri dan akan berpengaruh pula terhadap prestasi belajar siswa dan mahasiswa. Crow yang dikutip oleh A. Tabrani R (1994:121), memperjelas pentingnya motivasi belajar siswa atau motivasi dalam belajar, yaitu bahwa belajar harus diberi motivasi dengan berbagai cara sehingga minat yang dipentingkan dalam belajar itu dibangun dari minat yang telah ada pada diri anak. Mengingat motivasi belajar dan belajar mandiri sangat penting untuk mencapai pretasi belajar mahasiswa, maka peneliti merasa penting untuk melaksanakan penelitian secara lebih mendalam terkait dengan motivasi belajar dan tingkat belajar mandiri dalam kaitannya dengan prerstasi belajar mahasiswa program studi pendidikan geografi FKIP Universitas Tanjungpura tahun akademik 2018/2019. Oleh sebab itu dalam penelitian ini diberi judul: "Motivasi belajar dan tingkat belajar mandiri dalam kaitannya dengan prestasi belajar mahasiswa".

\section{Metode Penelitian}

Mengacu dalam permasalahannya, Metode dalam penelitian ini adalah penelitian deskriptif dengan pendekatan kuantitatif. Penelitian deskriptif adalah penelitian yang mendeskripsikan suatu gejala, peristiwa- peristiwa, kejadian yang terjadi pada saat sekarang. Metode deskriptif adalah metode yang bersifat menggambarkan keadaan daerah penelitian secara sistematis, faktual, dan akurat mengenai fakta-fakta, serta menganalisis hasil penelitian yang diperoleh (Surakhmad, 1982:139). Metode penelitian kuantitatif diartikan sebagai metode penelitian yang berlandaskan pada filsafat positivism, digunakan untuk meneliti pada populasi atau sampel tertentu.

Pengumpulan data menggunakan instrument penelitian angket, analisis data bersifat kuantitatif/statistik dengan tujuan untuk menguji hipotesis yang telah ditetapkan (Sugiyono, 2015, 14). Tahap-tahap pelaksanaan penelitian berdasarkan metode penelitian kuantitatif meliputi tahap persiapan, tahap pelaksanaan dan tahap akhir b Populasi dalam penelitian ini seluruh mahasiswa program studi pendidikan pendidikan geografi semester II, dan IV Tahun akademik 2018/2019.Adapun jumlah mahasiswa semester II adalah 35 orang dan mahasiswa semester IV berjumlah 35 orang.

Sampel penelitian ini merupakan sebagian dari populasi karena diambil dari sebagian dari jumlah mahasiswa semester, II dan IV dengan pertimbangan yaitu mahasiswa yang IPK menengah ke bawah masing-masing semester. Setelah dilakukan pertimbangan maka ditetapkan sampel untuk semester II sebanyak 16 orang dan semester IV sebanyak 23 orang. Secara teoritis variabel dapat didefinisikan sebagai atribut seseorang, atau objek yang mempunyai variasi antara satu orang dengan yang lain atau satu objek dengan objek yang lain (Hatch dan Farhady dalam Sugiyono, 2008:

60). Sehubungan dengan masalah penelitian, maka penelitian ini menggunakan dua variabel independen secara bersama-sama yaitu motivasi belajar dan belajar mandiri dengan satu variable dependen yaitu prestasi belajar. Data yang belajar dengan rentang skor 1-6 dan tingkat belajar mandiri mahasiswa dengan rentang 1-6. Alat pengumpulan data adalah angket yangh didukung oleh wawancara.

Analisis data skor dengan menjumlahkan dan selanjutnya dikategorikan dengan kategori rendah, sedang dan tinggi. Tingkat motivasi belajar mahasiswa dengan menjumlahkan perolehan skor dari 20 pertanyaan selanjutnya dikategorikan menjadi :

1. $\leq 40$ memiliki tingkat motivasi belajar dengan kategori rendah

2. 41-80 memiliki tingkat motivasi belajar tingkat sedang

3. 86 - 120, berarti Mahasiswa memiliki motivasi belajar yang tinggi

Tingkat belajar mandiri mahasiswa dengan menjumlahkan perolehan skor dari selanjutnya dikategorikan menjadi

1. 15-60, berarti mahasiswa memiliki tingkat belajar mandiri yang rendah

2. $61-90$, berarti mahasiswa memiliki tingkat belajar mandiri yang tinggi

Untuk menganalisis korelasi antara rata- rata tingkat motivasi belajar dengan belajar mandiri mahasiswa, dan untuk menganalisis korelasi antara rata-rata tingkat belajar mandiri dengan IPK mahasiswa, dianalisis dengan analisis korelasi dengan perhitungan Product Moment dari Pearson dilambangkan dengan $r$.

\section{HASIL DAN PEMBAHASAN}

1. Motivasi Belajar Mahasiswa
Skor
Mahasiswa Semester II 
Hasil pengisian angket mahasiswa se mester II tahun akademik 2018/2019 terhadap mahasiswa yang memiliki IPK $<5,55$ disajikan pada tabel berikut:

Tabel .1 Perolehan skor tingkat motivasi belajar Mahasiswa Semester II

\begin{tabular}{|c|r|r|r|l|c|c|}
\hline & & & & \multicolumn{3}{|c|}{ Kateori } \\
\cline { 6 - 7 } $\begin{array}{c}\text { No. } \\
\text { Subjek }\end{array}$ & $\begin{array}{c}\Sigma \\
\text { skor }\end{array}$ & skor & IPK & Rendah & Sedang & Tinggi \\
\hline 1 & 107 & 5,35 & 3,52 & & & $\sqrt{ }$ \\
\hline 2 & 96 & 4,8 & 3,52 & & & $\sqrt{ }$ \\
\hline 3 & 104 & 5,2 & 3,52 & & & $\sqrt{ }$ \\
\hline 4 & 94 & 4,7 & 3,52 & & & $\sqrt{ }$ \\
\hline 5 & 83 & 4,15 & 3,48 & & $\sqrt{ }$ & \\
\hline 6 & 90 & 4,5 & 3,48 & & & $\sqrt{ }$ \\
\hline 7 & 77 & 3,85 & 3,48 & & $\sqrt{ }$ & \\
\hline 8 & 100 & 5,0 & 3,48 & & & $\sqrt{ }$ \\
\hline 9 & 83 & 4,15 & 3,48 & & $\sqrt{ }$ & \\
\hline 10 & 102 & 5,1 & 3,48 & & & $\sqrt{ }$ \\
\hline 11 & 89 & 4,45 & 3,48 & & & $\sqrt{ }$ \\
\hline 12 & 96 & 4,80 & 3,43 & & & $\sqrt{ }$ \\
\hline 13 & 90 & 4,5 & 3,38 & & & $\sqrt{ }$ \\
\hline 14 & 81 & 4,05 & 3,33 & & $\sqrt{ }$ & \\
\hline 15 & 107 & 5,35 & 2,86 & & & $\sqrt{ }$ \\
\hline 16 & 87 & 4,35 & 2,81 & & & $\sqrt{ }$ \\
\hline
\end{tabular}

Dari tabel dapat diketahui motivasi belajar mahasiswa semester II tergolong motivasi kategori sedang sebanyak 4 orang atau $25 \%$, sedang mahasiswa yang memiliki motivasi belajar dengan kategori tinggi sebanyak 12 orang atau $75 \%$. Mahasiswa memiliki kmotivasi belajar dengan kategori tinggi, namun tidak diikuti dengan perolehan IPK yang tinggi.

b. Motivasi Belajar Mahasiswa Semester IV

Hasil pengisian angket mahasiswa semester IV tahun akademik 2018/2019 terhadap mahasiswa yang memiliki IPK menengah ke bawah disajikan pada tabel berikut:

Tabel 2. Perolehan skor tingkat motivasi belajar Mahasiswa Semester IV

\begin{tabular}{|c|c|c|c|l|c|c|}
\hline \multirow{2}{*}{$\begin{array}{c}\text { No. } \\
\text { Subjek }\end{array}$} & \multirow{2}{*}{$\begin{array}{c}\Sigma \\
\text { skor }\end{array}$} & skor & IPK & Rendah & Sedang & Tinggi \\
\hline 1 & 109 & 5,45 & $\begin{array}{c}3.4 \\
6\end{array}$ & & & $\sqrt{ }$ \\
\hline 2 & 95 & 4,75 & $\begin{array}{c}3.4 \\
6\end{array}$ & & & $\sqrt{ }$ \\
\hline 3 & 91 & 4,55 & $\begin{array}{c}3,4 \\
6\end{array}$ & & & $\sqrt{ }$ \\
\hline 4 & 90 & 4,50 & $\begin{array}{c}3,4 \\
6\end{array}$ & & & $\sqrt{ }$ \\
\hline 5 & 89 & 4.45 & $\begin{array}{c}3.4 \\
3\end{array}$ & & & $\sqrt{ }$ \\
\hline 6 & 67 & 2.35 & $\begin{array}{c}3,4 \\
2\end{array}$ & & $\sqrt{ }$ & \\
\hline 7 & 98 & 4,90 & $\begin{array}{c}3,4 \\
2\end{array}$ & & & $\sqrt{ }$ \\
\hline 8 & 103 & 5,15 & 3,4 & & & $\sqrt{ }$ \\
\hline
\end{tabular}

\begin{tabular}{|c|c|c|c|l|l|l|}
\hline 9 & 62 & 3,1 & $\begin{array}{c}3,4 \\
0\end{array}$ & & $\sqrt{ }$ & \\
\hline 10 & 107 & 5,35 & $\begin{array}{c}3,4 \\
0\end{array}$ & & & $\sqrt{ }$ \\
\hline 11 & 75 & 3,75 & $\begin{array}{c}3,3 \\
8\end{array}$ & & $\sqrt{ }$ & \\
\hline 12 & 95 & 4,75 & $\begin{array}{c}3,3 \\
5\end{array}$ & & & $\sqrt{ }$ \\
\hline 13 & 40 & 2,0 & $\begin{array}{c}3,3 \\
2\end{array}$ & $\sqrt{ }$ & & \\
\hline 14 & 89 & 4,45 & $\begin{array}{c}3,3 \\
2\end{array}$ & & & $\sqrt{ }$ \\
\hline 15 & 65 & 3,25 & $\begin{array}{c}3,3 \\
1\end{array}$ & & $\sqrt{ }$ & \\
\hline 16 & 93 & 4,65 & $\begin{array}{c}3,2 \\
8\end{array}$ & & & $\sqrt{ }$ \\
\hline 17 & 106 & 5,3 & $\begin{array}{c}3,2 \\
5\end{array}$ & & & $\sqrt{ }$ \\
\hline 18 & 79 & 3,95 & $\begin{array}{c}3,2 \\
0\end{array}$ & & $\sqrt{ }$ & \\
\hline 19 & 75 & 3,75 & $\begin{array}{c}3,1 \\
8\end{array}$ & & $\sqrt{ }$ & \\
\hline 20 & 108 & 5,4 & $\begin{array}{c}3,1 \\
7\end{array}$ & & & $\sqrt{ }$ \\
\hline 21 & 68 & 3,4 & $\begin{array}{c}3,0 \\
6\end{array}$ & & $\sqrt{ }$ & \\
\hline 22 & 97 & 4,85 & $\begin{array}{c}2,9 \\
2\end{array}$ & & & $\sqrt{ }$ \\
\hline 23 & 90 & 4,5 & $\begin{array}{c}2,5 \\
8\end{array}$ & & & $\sqrt{ }$ \\
\hline
\end{tabular}

Tabel dapat diketahui bahwa mahasiswa semester IV yang memiliki motivasi tingkat rendah sebanyak 1 orang atau 6,4,35\%, yang memiliki motivasi sedang 7 orang atau $30,43 \%$ dan yang memiliki motivasi tinggi 15 orang atau $65,22 \%$. Mahasiswa yang memiliki motivasi belajar kategori tinggi namun tidak diikuti dengan perolehan prestasi belajar yang tinggi.

\section{Tingkat Belajar Mandiri}

Hasil pengisian angket tentang belajar mandiri yang terdiri dari 15 pertanyaan dengan skor total skor total 90. Tingkat belajar mandiri dikategorikan menjadi dua kategori yaitu kategori tingkat belajar rendah dengan jumlah skor $\leq 60$, dan tingkat belajar mandiri kategori tinggi dengan jumlah skor 61-90. Perolehan skor dan perhitungan rata- rata disajikan hasil sebagai berikut:

a. Tingkat Belajar Mandiri Mahasiswa Semester II Tahun Akademik 2018/2019

Hasil pengisian angket belajar mandiri mahasiswa semester II tahun akademik 2018/2019 terhadap mahasiswa yang memiliki IPK $<5,55$ disajikan pada tabel berikut:

Tabel 3 Skor tingkat belajar mandiri Mahasiswa Semester II 


\begin{tabular}{|c|c|c|c|c|c|}
\hline \multirow{2}{*}{$\begin{array}{c}\text { No. } \\
\text { Subjek }\end{array}$} & $\begin{array}{c}\Sigma \\
\text { skor }\end{array}$ & skor & IPK & \multicolumn{3}{|c|}{ Kategori } \\
\hline & & & Rendah & Tinggi \\
\hline 1 & 76 & 5,07 & 3,52 & & $\sqrt{ }$ \\
\hline 2 & 67 & 4,47 & 3,52 & & $\sqrt{ }$ \\
\hline 3 & 74 & 4,93 & 3,52 & & $\sqrt{ }$ \\
\hline 4 & 67 & 4,47 & 3,52 & & $\sqrt{ }$ \\
\hline 5 & 54 & 3,6 & 3,48 & $\sqrt{ }$ & \\
\hline 6 & 68 & 4,53 & 3,48 & & $\sqrt{ }$ \\
\hline 7 & 57 & 3,8 & 3,48 & $\sqrt{ }$ & \\
\hline 8 & 70 & 4,67 & 3,48 & & $\sqrt{ }$ \\
\hline 9 & 60 & 4,0 & 3,48 & $\sqrt{ }$ & \\
\hline 10 & 60 & 4,0 & 3,48 & $\sqrt{ }$ & \\
\hline 11 & 62 & 4,13 & 3,48 & & $\sqrt{ }$ \\
\hline 12 & 73 & 4,87 & 3,43 & & $\sqrt{ }$ \\
\hline 13 & 66 & 4,4 & 3,38 & & $\sqrt{ }$ \\
\hline 14 & 56 & 3,73 & 3,33 & $\sqrt{ }$ & \\
\hline 15 & 84 & 5,6 & 2,86 & & $\sqrt{ }$ \\
\hline 16 & 50 & 3,33 & 2,81 & $\sqrt{ }$ & \\
\hline
\end{tabular}

Dari tabel dapat diketahui, mahasiswa semester II yang memiliki tingkat belajar mandiri kategori rendah ada 6 orang atau $37,5 \%$, dan mahasiswa yang memiliki tingkat belajar mandiri kategori tingi berjumlah 10 orang atau 62,5. Mahasiswa yang memiliki tingkat belajar mandiri dengan kategori tinggi namun tidak diikuti perolehan IPK yang tinggi

b. Tingkat Belajar Mandiri Mahasiswa Semester IV Tahun Akademik 2018/2019

Hasil pengisian angket belajar mandiri mahasiswa semester IV tahun akademik 2018/2019 terhadap mahasiswa yang memiliki IPK $<5,55$ disajikan pada tabel berikut:

Tabel 4. Skor tingkat belajar mandiri Mahasiswa Semester IV

\begin{tabular}{|c|c|c|c|c|c|}
\hline \multirow{2}{*}{$\begin{array}{r}\text { No. } \\
\text { Subjek }\end{array}$} & \multirow{2}{*}{$\begin{array}{c}\Sigma \\
\text { skor }\end{array}$} & \multirow[b]{2}{*}{ skor } & \multirow[b]{2}{*}{ IPK } & \multicolumn{2}{|c|}{ Kategori } \\
\hline & & & & Rendah & Tinggi \\
\hline 1 & 69 & 4,6 & 3,46 & & $\sqrt{ }$ \\
\hline 2 & 68 & 4,53 & 3,46 & & $\sqrt{ }$ \\
\hline 3 & 58 & 3.86 & 3,46 & $\sqrt{ }$ & \\
\hline 4 & 49 & 3,26 & 3,46 & $\sqrt{ }$ & \\
\hline 5 & 73 & 4,86 & 3,43 & & $\sqrt{ }$ \\
\hline 6 & 50 & 3,33 & 3,42 & $\sqrt{ }$ & \\
\hline 7 & 71 & 4,73 & 3,42 & & $\sqrt{ }$ \\
\hline 8 & 50 & 3,33 & 3,40 & $\sqrt{ }$ & \\
\hline 9 & 61 & 4,07 & 3,40 & & $\sqrt{ }$ \\
\hline 10 & 59 & 3,93 & 3,40 & $\sqrt{ }$ & \\
\hline 11 & 66 & 4,4 & 3,38 & & $\sqrt{ }$ \\
\hline 12 & 70 & 4,67 & 3,35 & & $\sqrt{ }$ \\
\hline 13 & 40 & 2,67 & 3,32 & $\sqrt{ }$ & \\
\hline 14 & 62 & 4,13 & 3,32 & & $\sqrt{ }$ \\
\hline 15 & 44 & 2,93 & 3,31 & $\sqrt{ }$ & \\
\hline 16 & 64 & 4,26 & 3,28 & & $\sqrt{ }$ \\
\hline 17 & 74 & 4,93 & 3,25 & & $\sqrt{ }$ \\
\hline 18 & 51 & 3,4 & 3,20 & $\sqrt{ }$ & \\
\hline 19 & 49 & 3,27 & 3,18 & $\sqrt{ }$ & \\
\hline 20 & 68 & 4,53 & 3,17 & & $\sqrt{ }$ \\
\hline 21 & 45 & 3,0 & 3,06 & $\sqrt{ }$ & \\
\hline 22 & 70 & 4,67 & 2,92 & & $\sqrt{ }$ \\
\hline 23 & 56 & 3,73 & 2,58 & $\sqrt{ }$ & \\
\hline
\end{tabular}

Dari tabel dapat diketahui, bahwa mahasiswa semester IV tergolong memiliki tingkat belajar mandiri kategori rendah 11 orang atau $47,83 \%$ dan tingkat belajar mandiri kategori tinggi 12 orang atau 52,17\%. Mahasiswa yang memiliki tingkat belajar mandiri dengan kategori tinggi tidak diikuti dengan perolehan IPK yang tinggi.

3. Korelasi ganda antara motivasi belajar dengan tingkat belajar mandiri secara bersama-sama dengan prestasi belajar (IPK) mahasiswa Semester II

Berdasarkan data yang terkumpul untuk setiap variable dihitung korelasi sederhananya sebagi berikut
a. Analisis
Korelas
Rata-rata
Skor
Motivasi
Belajar dengan
IPK
mahasiswa Semester II

Hasil perhitungan korelasi sederhana antara motivasi belajar dengan IPK dapat disajikan dalam tabel berikut: 
Tabel 5 Hasil Analisis korelasi antara motivasi belajar dengan IPK Mahasiswa

\begin{tabular}{|c|c|c|c|c|c|c|}
\hline \multirow{2}{*}{$\begin{array}{c}\text { Hasil } \\
\text { Perhitu } \\
\text { ngan }\end{array}$} & $\mathrm{N}$ & $\sum \mathrm{X}$ & $\sum \mathrm{Y}$ & $\sum \mathrm{X}^{2}$ & $\sum \mathrm{Y}^{2}$ & $\sum \mathrm{XY}$ \\
\cline { 2 - 6 } & 16 & 74,30 & 54,25 & 348,34 & 184,67 & 251,83 \\
\hline $\mathrm{r}_{\mathrm{xy}}$ & \multicolumn{5}{|c|}{$-0,060$} \\
\hline $\mathrm{Df}$ & \multicolumn{6}{|c|}{$16 \%$} \\
\hline $\mathrm{a}$ & \multicolumn{6}{|c|}{0,497} \\
\hline $\mathrm{r}_{\text {tabel }}$ & \multicolumn{6}{|c|}{} \\
\hline
\end{tabular}

Dari hasil perhitungan harga $r$ Product moment ternyata harga rhitung < harga tabel,sehingga Ha ditolak dan Ho diterima. Jadi kesimpulannya tidak ada hubungan positif dan nilai koefisien korelasi antara motivasi belajar dengan IPK mahasiswa sebesar 0,060 dengan tingkat hubungan sangat rendah.

b. Analisis Korelasi Rata-rata Skor Belajar Mandiri dengan IPK mahasiswa Semester II

Hasil perhitungan korelasi sederhana antara motivasi belajar dengan IPK dapat disajikan dalam tabel berikut

Tabel 6 Hasil Analisis korelasi antara tingkat belajar mandiri dengan IPK

\begin{tabular}{|c|c|c|c|c|c|}
\hline Hasil & \begin{tabular}{|l|l|}
$\mathrm{N}$ & $\mathrm{NX}$ \\
\end{tabular} & $\Sigma Y$ & $\overline{X^{2}}$ & $\Sigma Y^{2}$ & $5 X Y$ \\
\hline $\begin{array}{c}\text { Perhitu } \\
\text { nsan }\end{array}$ & \begin{tabular}{|l|l|}
10 & 69,60 \\
\end{tabular} & 54,25 & 308,20 & 184,67 & 236,00 \\
\hline$\overline{r_{y y}}$ & \multicolumn{5}{|c|}{$\overline{0,006}$} \\
\hline df & \multicolumn{5}{|c|}{16} \\
\hline$\alpha$ & \multicolumn{5}{|c|}{$5 \%$} \\
\hline rakel & \multicolumn{5}{|c|}{0,497} \\
\hline
\end{tabular}

Dari hasil perhitungan harga $r$ Product moment harga thitung < harga tabel, sehingga Ha ditolak dan Ho diterima. Jadi kesimpulannya tidak ada hubungan positif dan nilai koefisien korelasi antara motivasi belajar dengan IPK mahasiswa sebesar 0,006 dengan tingkat hubungan sangat rendah.

\section{c. Analisis korelasi rata-rata skor motivasi belajar} dengan belajar mandiri mahasiswa semester II

Hasil perhitungan korelasi sederhana antara motivasi belajar dengan belajar mandiri dapat disajikan dalam tabel berikut:

Tabel 7 Hasil perhitungan antara motivasi belajar dengan tingkat belajar mandiri Mahasiswa

\begin{tabular}{|c|c|c|c|c|c|}
\hline Hasal & \begin{tabular}{|l|l|}
$\mathrm{N}$ & $\mathrm{\Sigma X}$ \\
\end{tabular} & $\Sigma Y$ & $5 X^{2}$ & $5 Y^{2}$ & $\Sigma X Y$ \\
\hline $\begin{array}{c}\text { Perhitun } \\
\text { gan }\end{array}$ & $16 \mid 74,31$ & 69,60 & 347,34 & 308,21 & 326,64 \\
\hline$r_{x y y}$ & \multicolumn{5}{|c|}{0,968} \\
\hline df & \multicolumn{5}{|c|}{16} \\
\hline$a$ & \multicolumn{5}{|c|}{$5 \%$} \\
\hline Trabal & \multicolumn{5}{|c|}{0,497} \\
\hline
\end{tabular}

Dari hasil perhitungan harga $r$ Product ternyata harga $r_{\text {hitung }}>$ harga $t_{\text {tabel }}$, sehingga $\mathrm{Ha}$ diterima dan Ho ditolak Jadi kesimpulannya ada hubungan positif dan nilai koefisien korelasi antara motivasi belajar dengan tingkat belajar mandiri mahasiswa sebesar 0,968 dengan tingkat hubungan sangat kuat.

d. Analisis Korelasi ganda antara motivasi belajar dan tingkat belajar mandiri dalam kaitannya dengan prestasi belajar mahasiswa semester II

Setelah dihitung korelasi sederhananya, maka dengan rumus korelasi ganda diperoleh Ry.x = 0,216 . Pengujian signifikansi terhadap korelasi ganda dengan uji $\mathrm{F}$ diperoleh $\mathrm{Fh}=0,318$. Dengan $\mathrm{dk}$ pembilang 2 dan penyebut 13 dengan taraf kesalahan 5\% harga Ftabel ditemukan 3,80. Karena $\mathrm{F}_{\text {hitung }}<\mathrm{F}_{\text {tabel, }}$ maka Ha ditolak dan Ho diterima. Jadi koefisien korelasi ganda yang ditemukan tidak signifikan. Jadi tidak ada hubungan yang signifikan antara motivasi belajar dan tingkat belajar mandiri secara bersamasama dengan prestasi belajar.

4. Korelasi ganda antara motivasi belajar dengan tingkat belajar mandiri secara bersama-sama dengan prestasi belajar (IPK ) mahasiswa Semester IV

Berdasarkan data yang terkumpul untuk setiap variabel dihitung korelasi sederhananya sebagi berikut:

a. Analisis Korelasi Rata-rata Skor Motivasi

Belajar dengan IPK mahasiswa Semester IV

Hasil perhitungan korelasi sederhana antara motivasi belajar dengan IPK dapat disajikan dalam tabel berikut:

\begin{tabular}{||c|c|c|c|c|c|c||}
\hline $\begin{array}{c}\text { Hasil } \\
\text { Perhitu } \\
\text { ngan }\end{array}$ & $\mathrm{N}$ & $\sum \mathrm{X}$ & $\sum \mathrm{Y}$ & $\sum \mathrm{X}^{2}$ & $\sum \mathrm{Y}^{2}$ & $\sum \mathrm{XY}$ \\
\hline $\mathrm{r}_{\mathrm{xy}}$ & \multicolumn{5}{|c|}{0,019} \\
\hline $\mathrm{df}$ & \multicolumn{5}{|c|}{23} \\
\hline$\alpha$ & 75,50 & 444,38 & 248,74 & 326,85 \\
\hline $\mathrm{r}_{\text {tahel }}$ & \multicolumn{5}{|c|}{$5 \%$} \\
\hline
\end{tabular}


Dari hasil perhitungan harga $r$ Product ternyata harga rhitung < harga ttabel, sehingga Ha ditolak dan Ho diterima. Jadi kesimpulannya tidak ada hubungan positif dan nilai koefisien korelasi antara motivasi belajar dengan prestasi belajar IPK mahasiswa semester IV sebesar 0,019. Interpretasi terhadap koefisien korelasinya dengan kategori hubungan sangat rendah.

b. Analisis Korelasi tingkat belajar mandiri dengan IPK mahasiswa.

Hasil perhitungan korelasi sederhana antara belajar $\mathrm{m}$,andiri dengan IPK dapat disajikan dalam tabel berikut:

Tabel 9 Analisis korelasi antara Tingkat belajar Mandiri dengan IPK Mahasiswa

\begin{tabular}{|c|c|c|c|c|c|c|}
\hline $\begin{array}{c}\text { Hasil } \\
\text { Perhitu }\end{array}$ & $\mathrm{N}$ & $\sum \mathrm{X}$ & $\sum \mathrm{Y}$ & $\sum \mathrm{X}^{2}$ & $\sum \mathrm{Y}^{2}$ & $\sum \mathrm{XY}$ \\
\cline { 2 - 6 } & 23 & 69,60 & 54,25 & 308,20 & 184,67 & 236,00 \\
\hline $\mathrm{r}_{\mathrm{xy}}$ & \multicolumn{5}{|c|}{3,152} \\
\hline $\mathrm{df}$ & \multicolumn{5}{|c|}{32} \\
\hline$\alpha$ & \multicolumn{5}{|c|}{0,413} \\
\hline $\mathrm{r}_{\text {tabel }}$ & \multicolumn{5}{|c|}{0,4} \\
\hline
\end{tabular}

Dari hasil perhitungan harga $r$ Product moment ternyata harga rhitung $>$ harga tabel, sehingga $\mathrm{Ha}$ diterima dan Ho ditolak Jadi kesimpulannya ada hubungan positif dan nilai koefisien korelasi antara motivasi belajar dengan tingkat belajar mandiri mahasiswa sebesar 0,968. Interpretasi terhadap koefisien korelasinya dengan kategori hubungan sangat kuat.

c. Analisis korelasi motivasi belajar dengan tingkat belajar mandiri Mahasiswa

Berdasarkan rekapitulasi skor dan perhitungan rata-rata yang diperoleh mahasiswa dari jawaban angket motivasi belajar dan tingkat belajar mandiri (Lampiran 9 halaman) disajikan pada tabel berikut:

Tabel 10 Analisis korelasi antara Motivasi Belajar dengan tingkat belajar mandiri Mahasiswa Semester IV

\begin{tabular}{|c|c|c|c|c|c|c|}
\hline $\begin{array}{c}\text { Hasil } \\
\text { Perhitun } \\
\text { gan }\end{array}$ & $\mathrm{N}$ & $\sum \mathrm{X}$ & $\sum \mathrm{Y}$ & $\sum \mathrm{X}^{2}$ & $\sum \mathrm{Y}^{2}$ & $\sum \mathrm{XY}$ \\
\hline $\mathrm{r}_{\mathrm{xy}}$ & $\mathbf{5}$ & 74,30 & 69,60 & 347,34 & 308,21 & 326,64 \\
\hline $\mathrm{df}$ & \multicolumn{5}{|c|}{0,746} \\
\hline$\alpha$ & \multicolumn{5}{|c|}{23} \\
\hline $\mathrm{r}_{\text {tahel }}$ & \multicolumn{5}{|c|}{0,413} \\
\hline
\end{tabular}

Dari hasil perhitungan harga $r$ Product ternyata harga rhitung > harga tabel, sehingga Ha diterima dan Ho ditolak Jadi kesimpulannya ada hubungan positif dan nilai koefisien korelasi antara motivasi belajar dengan tingkat belajar mandiri mahasiswa semester IV sebesar 0,746 Interpretasi terhadap koefisien korelasinya dengan tingkat hubungan sangat kuat.

d. Analisis Korelasi ganda antara motivasi belajar dan tingkat belajar mandiri dalam kaitannya dengan prestasi belajar mahasiswa semester II

Berdasarkan data yang terkumpul untuk setiap variabel dan setelah dihitung korelasi sederhananya, maka dengan rumus korelasi ganda diperoleh Ry.x 1 х $2=4,709$. Pengujian signifikansi terhadap korelasi ganda dengan uji $\mathrm{F}$ diperoleh $\mathrm{Fh}=$ 10,479. Bila dibandingkan dengan harga $F$ dengan $\mathrm{dk}$ pembilang 2 dan penyebut 20 dengan taraf kesalahan 5\% harga $\mathrm{F}_{\text {tabel }}$ ditemukan 3,80. Ternyata harga Fhitung lebih besar dari Ftabel $(4,709>3,80)$.

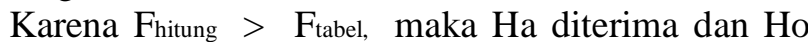
ditolak. Jadi koefisien korelasi ganda yang ditemukan signifikan. Jadi ada hubungan yang signifikan antara motivasi belajar dan tingkat belajar mandiri secara bersama-sama dengan prestasi belajar mahasiswa semester IV.

\section{KESIMPULAN}

Berdasarkan sub masalah dan tujuan khusus penelitian, maka untuk menjawab permasalahan penelitian berdasarkan hasil penelitian dan analisisi data dapat disimpulkan sebagai berikut:

1. Motivasi belajar mahasiswa semester 2 dengan IPK $<5,50$ umumnya berada pada kategori tinggi, namun belum diikuti dengan perolehan prestasi belajar (IPK) yang tinggi.

2. Umumnya mahasiwa semester IV dengan IPK $<5,50$ sudah memiliki motivasi belajar dengan kategori tinggi tetapi tidak diikuti dengan perolehan IPK yang tinggi.

3. Berdasarkan perhitungan korelasi ganda dengan uji $\mathrm{F}$ pada mahasiswa semester II tidak ada hubungan yang signifikan antara motivasi belajar dengan tingkat belajar mandiri secara bersama-sama dengan prestasi belajar mahasiswa. Oleh sebab itu mahasiswa perlu dibimbing untuk meningkatkan motivasi belajar mandiri dan tingkat belajar mandiri untuk mencapai prestasi belajar yang tinggi. 
4. Berdasarkan perhitungan korelasi ganda dengan uji $\mathrm{F}$ pada mahasiswa semester IV koefisien korelasi ganda yang ditemukan signifikan (dapat diberlakukan untuk populasi dimana sampel diambil). Jadi ada hubungan yang signifikan antara motivasi belajar dengan tingkat belajar mandiri secara bersama-sama dengan perolehan prestasi belajar. Untuk itu mahasiswa harus tetap mempertahankan sikap positif terhadap diri sendiri dan terus berusaha untuk meningkatkan diri sehingga memiliki rasa percaya diri yang tinggi. Mahasiswa dapat meminta orang lain untuk memberikan komentar terhadap kemampuan yang miliki dan berusaha untuk memperbaiki kekurangan yang ditemukan.

\section{DAFTAR PUSTAKA}

Djamarah, Syaiful Bahri, (1994). Prestasi Belajar dan kompetensi Guru. Surabaya: Usaha Nasional.

Djauhar Siddiq Isniatun, Munawaroh,Sungkono, (2008). Pengembangan Bahan Pembelajaran SD, Jakarta: Dirjen Dikti Depdiknas.
Nasution. 1982. Teknologi Pendidikan. Bandung: Bumi Aksara.

Sugiyono, (2009). Metode Penelitian Pendidikan, Bandung. CV. Alfabeta.

Syaiful Bahri Djamarah, (2008). Psikologi Belajar Edisi II. Jakarta : Rineka Cipta. Udin

S.Winataputra,dkk. (1997). Strategi Belajar Mengajar. Jakarta: Depdikud, UT

W.S. Winkel. (1996). Psikologi Pengajaran, Jakarta: Grasindo

Sugiyono (2009). Statistik untuk Penelitian, Bandung, cv Alfabeta

Syaiful Bahri Djamarah, (2008). Psikologi Belajar Edisi II. Jakarta : Rineka Cipta. Udin

S. Winataputra,dkk. (1997). Strategi Belajar Mengajar. Jakarta: Depdikud, UT

W.S. Winkel. (1996). Psikologi Pengajaran, Jakarta: Grasindo. 